\title{
Synchrony in the phenology of a culturally iconic spring flower
}

\author{
Tim H. Sparks • Tadeusz Mizera • Wanda Wójtowicz • \\ Piotr Tryjanowski
}

Received: 12 October 2010 /Revised: 2 April 2011 / Accepted: 2 April 2011 /Published online: 6 May 2011

(C) The Author(s) 2011. This article is published with open access at Springerlink.com

\begin{abstract}
We examine the flowering phenology of the cultural iconic Spring Snowflake Leucojum vernum, a considerable tourist attraction, recorded from two sites in western Poland. Flowering dates at the two sites were closely correlated but about 6 days later at the more natural area. The end of flowering was associated with the start of canopy leafing. Early flowering was related to a longer flowering season which may benefit ecotourism under future climate warming.
\end{abstract}

Keywords Ecosystem services · First flowering date ·

Leucojum vernum . Spring snowflake

\section{Introduction}

Ecosystems services are normally considered in four categories: provisioning, regulating, supporting and cultural (Boyd and Wainger 2002). The monetary value of the latter is more difficult to estimate since it includes recreation, cultural and spiritual use of the countryside as well as ecotourism. In some countries, ecotourism is well developed and easy to quantify, e.g. autumn tourists, including "leaf peepers", are estimated to spend US\$375 $\mathrm{m}$ in Vermont alone (Boston Globe, September 27 2009). In Japan, both autumn

T. H. Sparks $(\bowtie) \cdot$ T. Mizera $\cdot$ P. Tryjanowski Institute of Zoology, Poznań University of Life Sciences, Wojska Polskiego $71 \mathrm{C}$, 60-625 Poznań, Poland

e-mail: thsparks@btopenworld.com

W. Wójtowicz

Adam Mickiewicz University Botanical Garden,

Dąbrowskiego 165,

60-594 Poznań, Poland colour watching ("momijigari”) and viewing of spring flowers ("hanami") are hugely important; 10 million visitors a year visit the famous 59-ha Arashiyama National Forest near Kyoto (Fukamachi et al. 2000), and when cherry flowering coincides with public holidays this attracts an additional 1.4 million tourists to Hirosaki (London Times, June 9 2005). Cherry flowering is also a huge attraction in Korea, China and across North America where an estimated 700,000 visitors visit Washington D.C. for the cherry blossom festival (National Geographic, April 5 2002). The ability to predict the timing of these displays is of great importance to the success of these cultural events.

In many other situations, it is difficult to quantify either the number of ecotourists or the economic value of recreation. One such example in Eastern Europe is the forest species Spring Snowflake Leucojum vernum (Polish name Śnieżyca wiosenna) which is listed as endangered on the Polish Red List of Plants and Fungi (Zarzycki and Szelag 2006). Like many vernal species, its appearance is keenly awaited as a harbinger of spring and its flowering is a considerable attraction for the Polish people. The small woodland nature reserve of Śnieżycowy Jar was designated in 1975 as a 3-ha reserve to protect one of the few lowland Polish sites of the species and has subsequently been extended to 9 ha with a further 6-ha buffer. The timing and the length of the floral display may be crucial to its popularity.

Because of its cultural iconic status, records have been kept of Spring Snowflake flowering phenology, and in this paper we compare 16 years of records from the Śnieżycowy Jar reserve with records kept in the nearby city of Poznań. The latter, planted, location also provides other phenophase records for Spring Snowflake which are examined in relation to one another and to leaf-out of canopy species. 


\section{Materials and methods}

First flowering date (the date of the first open flower; FFD) of Spring Snowflake was recorded at Śnieżycowy Jar $\left(52.6^{\circ} \mathrm{N}, 17.0^{\circ} \mathrm{E}\right)$ for $1994-2009$. Records of FFD of Spring Snowflake for the same years were obtained from the Poznań Botanic Garden $\left(52.2^{\circ} \mathrm{N}, 16.5^{\circ} \mathrm{E}\right)$ about $20 \mathrm{~km}$ south of Śnieżycowy Jar in the same, fairly flat landscape. The Botanic Garden also provided observation dates of first flower bud, first flower senescence, last flower bud and end of flowering of Spring Snowflake and the first leafing dates (leaf fully open) of Hazel Corylus avellana, Silver Birch Betula pendula, Horse Chestnut Aesculus hippocastanum and Larch Larix decidua. First leafing dates of these four species were averaged to estimate canopy leaf-out date. All dates were converted to day of the year $(1=$ Jan 1, etc. $)$ prior to analysis. Botanic Garden observations were made on a daily basis; those from Śnieżycowy Jar several times weekly.

Mean monthly temperatures, collected at the Poznan Botanic Garden meteorological station according to WMO guidelines, were obtained for the same years.

Standard regression and correlation methods were used to compare events with one another and with temperature.

\section{Results}

The FFDs of Spring Snowflake from Śnieżycowy Jar and Poznań are shown in Fig. 1. The two sites were significantly positively correlated $\left(r_{14}=0.81, p<0.001\right)$ although those from Śnieżycowy Jar were significantly later by an average

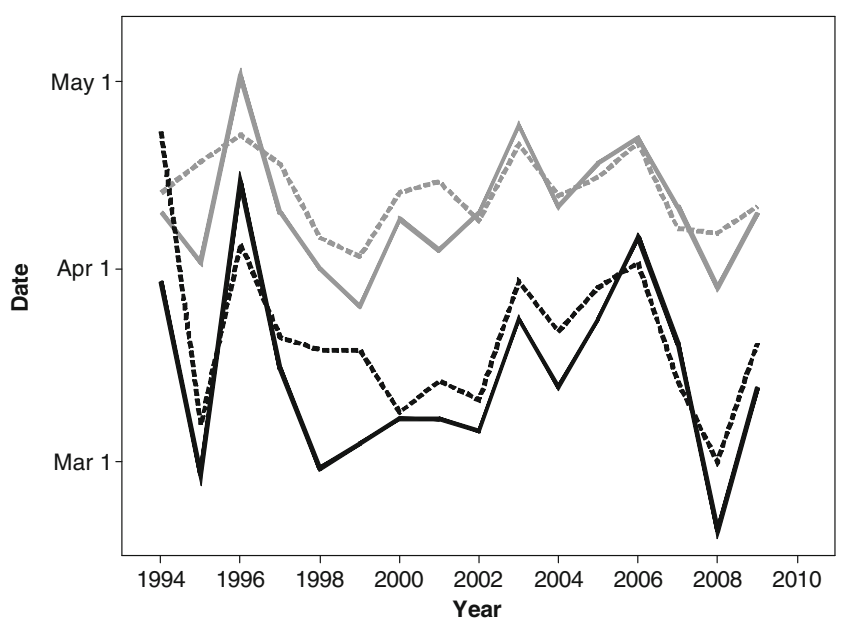

Fig. 1 First flowering date of Spring Snowflake Leucojum vernum from the Poznan Botanic Garden (solid black line) and from the Śnieżycowy Jar nature reserve (dotted black line). The end of flowering at the Botanic Garden (solid grey line) is also shown in comparison to canopy leaf-out (dotted grey line) of 6.3 days (Śnieżycowy Jar mean March 21, Poznań mean March 14, paired $t_{15}=2.90, p=0.011$ ).

The five phases of Spring Snowflake phenology from Poznań were highly correlated with one another (Fig. $1 ; r_{14}$ from 0.67 to 0.96 , all $p<0.004)$. There was a close association between the end of flowering of Spring Snowflake and canopy leaf-out (Fig. $1, r_{14}=0.77, p<0.001$ ).

All phases were closely correlated with temperatures in February unless otherwise stated; first flower bud with January temperature $\left(r_{14}=-0.89, p<0.001\right)$; first flower (Poznań $r_{14}=-0.83, p<0.001$; Śnieżycowy Jar $r_{14}=-0.80$, $p<0.001)$; first flower senescence $\left(r_{14}=-0.80, p<0.001\right)$, last flower bud $\left(r_{14}=-0.74, p=0.001\right)$, end of flowering $\left(r_{14}=-0.69, p=0.003\right)$ and leaf-out with March temperature $\left(r_{14}=-0.72, p=0.002\right)$.

The regression coefficient of last flowering date on FFD in Poznań was $0.588 \pm 0.082$ days/day $\left(F_{1,14}=51.90\right.$, $\left.R^{2}=78.8 \%, p<0.001\right)$, i.e. significantly less than unity, thus the flowering season (which varied from 11 to 39 days) was shorter when FFD was later and vice versa.

\section{Discussion}

Spring Snowflake is a culturally iconic species in Poland. Its first flowering is an eagerly awaited event signalling the end of winter. The small nature reserve at Śnieżycowy Jar receives a substantial, but unquantified, number of visitors during the flowering period. The flowering of Spring Snowflake is also a big attraction wherever it occurs.

In other countries, similar spring flowering attractions exist, for example Snowdrop Galanthus nivalis or Bluebell Hyacinthoides nonscripta in the UK, but rarely do they reach the levels of cultural importance of the "hanami" in Japan. Globally, the value of this aspect of cultural ecosystem services must be immense and it is likely that we seriously underestimate the value of biodiversity as a consequence.

The recorded date for the first flowering of Spring Snowflake was, on average, 6 days earlier in Poznań than in the nature reserve at Śnieżycowy Jar only $20 \mathrm{~km}$ away, compatible with an estimated earlier start of season by 5.7 days in urban areas in the eastern USA (White et al. 2002).

We have also shown that the end of flowering in Spring Snowflake was associated with the leaf-out of the canopy which reduces sunlight for further plant development. The close agreement in FFD phenology between the two sites suggests that Spring Snowflake is a reliable phenological measure since its flowering is eagerly awaited and likely to be recorded with precision. Earlier FFD in this species was associated with a longer 
flowering duration. Under future climate warming, a longer flowering period might thus be enjoyed by more ecotourists, providing that this does not result in a less intense colour spectacle, i.e. fewer flowers at any one time.

Acknowledgements We thank M. Górska-Zajączkowska (Poznań Botanic Garden) and J. Andrzejczyk (Łopuchówko Forest Division) for help in obtaining the flowering data.

Open Access This article is distributed under the terms of the Creative Commons Attribution Noncommercial License which permits any noncommercial use, distribution, and reproduction in any medium, provided the original author(s) and source are credited.

\section{References}

Boyd J, Wainger L (2002) Landscape indicators of ecosystem service benefits. Am J Agric Econ 84:1371-1378

Fukamachi K, Oku H, Kumagai Y, Shimomura A (2000) Changes in landscape planning and land management in Arashiyama National Forest in Kyoto. Landsc Urban Plann 52:73-87

White MA, Nemani RR, Thornton PE, Running SW (2002) Satellite evidence of phenological differences between urbanized and rural areas of the eastern United States deciduous broadleaf forest. Ecosystems 5:260-273

Zarzycki K, Szelagg Z (2006) Red list of vascular plants in Poland. In: Mirek Z, Zarzycki K, Wojewoda W, Szelag Z (eds) Red list of plants and fungi in Poland. Instytut Botaniki im. W. Szafera PAN, Kraków, pp 9-20 